\section{THE SENSITIVITY OF L1 \\ ENGLISH - L2 THAI \\ LANGUAGE LEARNERS TO \\ ERRORS IN BASIC THAI \\ SERIAL VERB \\ CONSTRUCTIONS}

\section{Kamolchanok Hongthong ${ }^{1}$}

\begin{abstract}
The present study concerned the sensitivity to unacceptable basic Thai serial verb constructions (thereinafter called SVCs) among native speakers of English who learn Thai. The objectives were to test English learners of Thai on distinguishing between acceptable and unacceptable SVCs, and to specify the characteristics of errors that tend to be problematic to them. The scope of this study was limited to basic SVCs that consist of the juxtaposition of only two nongrammaticalized and non-complement taking verbs. The subjects in this experiment were ten English undergraduates and postgraduates in the Thai Studies program. The data elicitation methods were an untimed acceptability judgment test and a think-aloud protocol. A set of 30 individual Thai sentences, each with phonetic transcription, gloss and an English translation - some of which were accurate and others were not - were presented and the subjects were then asked to give their verbal reports on each
\end{abstract}

\footnotetext{
${ }^{1}$ Ph.D. Candidate, Department of Linguistics, Faculty of Arts, Chulalongkorn University, Bangkok, Thailand
}

of the sentences. The audio-recorded data were coded and analyzed. The results revealed that learners are relatively insensitive to malformed SVCs, particularly redundant ones (46.67\%).

\section{Introduction}

Aikhenvald (2006:1) defined Serial Verb Constructions (thereinafter SVCs) as "a sequence of verbs which act together as a single predicate, without any overt marker of coordination, subordination, or syntactic dependency of any other sort. Within an SVC, the individual verbs may have same, or different, transitivity values. SVCs may also share core and other arguments which may or may not be explicitly expressed". According to Aikhenvald, the phenomenon is commonly found in languages spoken in Africa, Oceania, Amazonia and Southeast Asia, including Thai.

The scope of this study covered only basic Thai SVCs which contain a pair of verbs co-occuring together in a fixed linear order. Both verbs must be nongrammaticalized and non-complement taking verbs. By these criteria, verbs, such as jù:', wâ:, dâj, thù:k, hâj were excluded from this study because they were grammaticalized, i.e. they were derived from lexical verbs whose lexical meanings were lost in some certain linguistic contexts and later developed new grammatical functions to express grammatical meanings ${ }^{2}$. Here are some examples.

\footnotetext{
2 The table shows the lexical meanings and grammatical functions of gramaticalized verbs.
} 
(1) knăw là:p ná:m jù: he take a shower live, be located

'He is taking a shower.' (prog/durative)

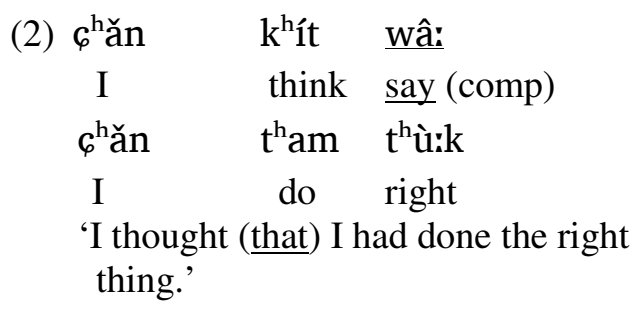

Moreover, complement-taking verbs or ones which require the presence of another verb to complete their sense, like jàrk 'want' or wăy 'hope' or rî̀m 'begin' were also excluded.

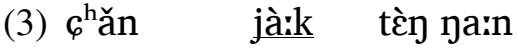 \\ I want marry \\ 'I want to get married.'}

In brief, verbs under investigation must be full-fledged lexical verbs that can stand alone on their own right.

The current study is based on Thepkanjana's (2006) research regarding the properties of

\begin{tabular}{|l|l|l|}
\hline Verbs & \multicolumn{1}{|c|}{$\begin{array}{c}\text { Lexical } \\
\text { meanings }\end{array}$} & \multicolumn{1}{|c|}{$\begin{array}{c}\text { Grammatical } \\
\text { functions }\end{array}$} \\
\hline jù: & live, be located & $\begin{array}{l}\text { progressive/ durative } \\
\text { aspect marker }\end{array}$ \\
\hline wâ: & say & complementizer \\
\hline dâj & get & past tense marker \\
\hline $\mathrm{t}^{\mathrm{h}}$ ù:k & $\begin{array}{l}\text { come into } \\
\text { contact with }\end{array}$ & passive marker \\
\hline hâj & give & beneficial marker \\
\hline
\end{tabular}

events denoted by 4 patterns of nongrammaticalized and non-complement taking basic SVCs. Her brief findings are as follows:
1) Primary action verb + Non-primary action verb

Primary action here refers to an action in which it can be obviously perceived which part of the body is being used, e.g. walk, nod, sit, look, eat. Conversely, in a nonprimary action, it is not obvious which part of the body the action is carried out by, e.g. hurry, pretend, practice, etc. The initial verb indicates the physical manner of performing an action expressed by another verb in the series.

(4) kăw kwàk mu: rî:ak chăn $^{\text {hà }}$ call on me
he wave 'He called on me by waving his hand.'

\section{2) Posture verb + Action verb}

The subject of the sentence performs an action denoted by the second verb while he is in the body posture expressed by the first verb.

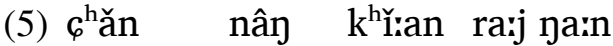

$$
\begin{aligned}
& \text { I sit write report } \\
& \text { 'I sat writing a report.' }
\end{aligned}
$$

\section{3) Primary action verb + Primary action verb}

The same agent carries out a sequence of two different physical actions. The second verb is interpreted as the purpose. There 
may be time lapse between the two sequential events.

(6) khăw pîn kà nǒm pạ kin he toast bread eat 'He toasted a slice of bread to eat.'

Primary action verb + Physical
process

The construction is interpreted as a causeeffect sequence of events which occur at the same place and in very close sequence without any noticeable delay.

$\begin{array}{clll}\text { (7) k kăw } & \text { pa: } & \text { kê:w } & \text { tè:k } \\ \text { he } & \text { throw } & \text { glass } & \text { broken }\end{array}$ 'He threw a glass and it broke.'

Later Thepkanjana (2008) also investigated the serializability of Thai basic SVCs and argued that verbs do not serialize freely. There are two constraints that prevent a couple of random verbs from occurring together. One is known as schematic constraint with regard to syntactic and semantic aspects of the four aforementioned patterns. The other is pragmatic constraint which associates with practical real-world knowledge.

Consequently, the current paper was interested in whether non-native Thai language learners are sensitive enough to overcome such constraints by detecting erroneous SVCs. The researcher intentionally created a number of unacceptable sentences containing SVCs which are anomalous in four different ways, namely, verb alternation, verb choice, temporal gap, and redundancy.

\section{1) Verb alternation}

This characteristic of error refers to an alternation of verb order in the four patterns of basic Thai SVCs discussed earlier by Thepkanjana (2006). For example, the sentence below contains the two verb classes

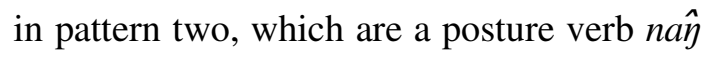
('sit') and an action verb ró: $\eta p^{h} l e: \eta$ ('sing a song'). This pair of verbs expresses a pragmatically possible event in that one can sit and sing a song at the same time. It should be noted that before the alternation, both verbs neither violated schematic nor pragmatic constraints, but once the position between them was switched, it resulted in an unacceptable SVC marked with an asterisk $(*)$, like sentence (8).

$$
\begin{array}{ccc}
\text { (8) * } \mathrm{k}^{\text {hăw }} \text { ró:n p phle:n } & \text { nây } \\
\text { he } & \text { sing a song } & \text { sit } \\
\text { * 'He sang. ( ) sat.' } &
\end{array}
$$

Verb alternation errors on the data elicitation tool were created by selecting a pair of verbs (from one of the four patterns mentioned above) that together can express an action or event associated with reality and switching the position of the verbs to create an ungrammatical sentence.

\section{2) Verb choice}

This characteristic of error deals with the violation of the pragmatic constraint, as one of the verbs contradicts reality. Even though the SVC in sentence (9) contains the concatenation of a posture verb and an action verb which are grammatically possible (as explained above in Pattern 2), the verb no:n ('sleep') expresses a manner in 
which it would be impossible to perform the action of $t^{\text {ham }}$ ?a: hănn ('cook food'). Therefore, it becomes an unacceptable sentence.

$$
\begin{gathered}
\text { (9) * } \mathrm{k}^{\mathrm{h}} \text { ăw nə:n tham Pa: hă:n } \\
\text { he sleep cook food } \\
\text { * 'He cooked in his reclining posture.' }
\end{gathered}
$$

To create this type of error, the researcher picked a pair of verbs from two classes in any of the four patterns that obey the schematic constraint, but one of the verbs in the series could not convey a conceivable event according to real-world knowledge.

\section{3) Temporal gap}

This characteristic of error involves a noticeable time span between the events expressed by verbs in SVCs. For example, when two primary action verbs in Pattern 3 co-occur together, they denote an action purpose kind of sequential event that takes place at (almost) the same time and in the same place. Although the pair of verbs in sentence (10) are primary action verbs, the second verb 2j:k ('leave') is not an objective event that occurs right after the initial verb pit ('turn off'); in other words, together they did not denote a prototypical episodic event.

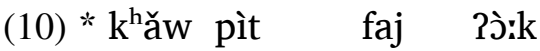

$$
\begin{aligned}
& \text { he turn off light leave } \\
& \text { cà:k hô:y } \\
& \text { from room } \\
& \text { * 'He turned the light off. ( ) left the } \\
& \text { room.' }
\end{aligned}
$$

The unacceptable SVCs were made by concatenating two verbs that obey the schematic constraint in any of the four patterns, but violate the pragmatic constraint because there was a noticeable time span between actions or events denoted by the initial verb and the second verb in the series.

\section{4) Redundancy}

This characteristic of error concerns an unnecessary occurrence of the argument of the verbs in SVCs which can be removed without damaging the meaning of the sentence. For example, sûu'a 'shirt' in sentence (11) is the object of the transitive verbs sák 'wash' and rîtt 'iron'. To correct the sentence, the first sû:a should be deleted.

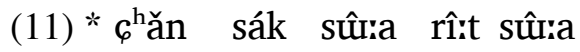

$$
\begin{aligned}
& \text { I wash shirt iron shirt } \\
& \text { * 'I washed a shirt (or shirts) and ironed }
\end{aligned}
$$

The malformed SVCs relating to this characteristic of error were created by adding an excessive argument shared by the two verbs in the construction. The argument may appear in a duplicate form (like the example above) or a pronoun co-referential with the argument, such as man ('it').

Even though the basic SVCs consist of only two verbs, it can be inferred from related literature that it might not be easy for nonnative speakers to formulate, as they require syntactic, semantic and pragmatic knowledge to overcome the verb combinations' diversity and complexity, as well as the constraints. In 
addition, the researcher's personal teaching experiences support the hypothesis that L2 Thai learners face difficulties in both production and comprehension of SVCs. The current research aims to address this issue by examining to what extent SCVs are problematic for learners of Thai as a foreign language and pinpoint the problematic characteristics.

\section{Methodology}

\section{Research questions}

1. To what extent can English learners distinguish between acceptable and unacceptable basic Thai SVCs?

2. What kinds of errors in basic Thai SVCs tend to be problematic for English learners of Thai?

\section{SVCs under investigation}

The study focused on basic nongrammaticalized and non-complement taking SVCs in Thai. The data elicitation tool consisted of 30 Thai sentences in total. There were 24 target sentences ${ }^{3}$ which contained an equal number of acceptable and unacceptable SVCs. The unacceptable ones can be divided into four erroneous characteristics; namely verb alternation, verb choice, redundancy and temporal gap. The other six were distracters ${ }^{4}$ which were wellformed and SVC-free sentences. They were included in the task to prevent the participants from guessing which language feature was being observed. The 30

\footnotetext{
${ }^{3}$ see Appendix A

${ }^{4}$ see Appendix B
}

sentences were administered in a randomized order.

It was assumed that all Thai words appearing in the judgment task were in the learners' repertoire and the difficulty level was not beyond the domain of an intermediate proficiency level because all the vocabulary had been taken from the word bank compiled by the instructors of the Thai Studies program at the University of Leeds. Prior to the experiment, the researcher checked the acceptability status of all sentences in the task by asking 20 native Thais to perform an acceptability judgment test (henceforth, AJT). The Thai informants were those doing Master's or $\mathrm{PhD}$ at the University of York in 2010. They made a unanimous judgment on the acceptability status of all target items and distracters, owing to the fact that they were fairly simple to native speakers.

\section{Selection of participants}

The sample of English speakers learning Thai was recruited from those attending Thai lessons provided by the Thai Studies program at the University of Leeds. One of the instructors confirmed that the target constructions were introduced to learners towards the end of their first year. She also kindly emailed her students who met the qualifications of the study. 
Table 1 The components of the task.

\begin{tabular}{|l|c|c|c|}
\hline \multicolumn{1}{|c|}{ Characteristics of errors } & Acceptable items & Unacceptable items & Total \\
\hline Verb alternation & 3 & 3 & 6 \\
\hline Verb choice & 3 & 3 & 6 \\
\hline Redundancy & 3 & 3 & 6 \\
\hline Temporal gap & 3 & 3 & 6 \\
\hline Distracters & - & - & 6 \\
\hline
\end{tabular}

There were 10 subjects $^{5}$, four females and six males, aged between 21 and 34 years old (mean $=26.8)$ who voluntarily joined the study. Due to the limited numbers of students, the researcher had to combine eight undergraduates and two postgraduates in the study. None of the subjects were enrolled in any other Thai course outside the campus. In their second year, all the students participate in an obligatory one-year exchange program to Chiang Mai University, and then return to the UK to complete the final two years of

${ }^{5}$ The table presents the number of students in the Thai Studies program in the academic year of 2010.

\begin{tabular}{|c|c|c|c|}
\hline $\begin{array}{l}\text { Levels of } \\
\text { study }\end{array}$ & $\begin{array}{c}\text { The } \\
\text { total } \\
\text { number } \\
\text { of } \\
\text { students }\end{array}$ & $\begin{array}{c}\text { The } \\
\text { number } \\
\text { of } \\
\text { students } \\
\text { that have } \\
\text { learned } \\
\text { SVCs } \\
\text { and are } \\
\text { native } \\
\text { speakers } \\
\text { of } \\
\text { English }\end{array}$ & $\begin{array}{l}\text { The number } \\
\text { of students } \\
\text { who met the } \\
\text { criteria and } \\
\text { volunteered } \\
\text { to join the } \\
\text { study }\end{array}$ \\
\hline $1^{\text {st }}$ year & 6 & \multicolumn{2}{|c|}{$\begin{array}{l}\text { They have not been } \\
\text { introduced to SVCs yet. }\end{array}$} \\
\hline $2^{\text {nd }}$ year & \multicolumn{3}{|c|}{$\begin{array}{l}\text { It is obligatory for all of them to } \\
\text { spend a year in Chiang Mai. }\end{array}$} \\
\hline $3^{\text {rd }}$ year & 4 & 3 & 3 \\
\hline $4^{\text {th }}$ year & 8 & 7 & 5 \\
\hline Postgraduate & 3 & 3 & 2 \\
\hline
\end{tabular}

study. Other foreign languages the participants reported knowing were either French or German because it is a compulsory course from Year 7 to Year 11, on the British National Curriculum. Like English, these two foreign languages are non-serializing languages.

\section{Data elicitation methods}

The AJT was deliberately employed because it forced the participants to look directly at the target items in question. Compared to other data collecting methods, such as a picture description or a writing task, it could be the case that the subjects may avoid producing the language feature of the research's interest. The AJT involved the participants deciding whether the list of sentences were well- or ill-formed, and also allowed participants as much time to complete the session as was necessary. In addition, the participants were also encouraged to locate the errors and to rectify parts of sentences deemed ungrammatical or illogical. Their answers and supporting explanations helped ensure that the reasons behind their judgment were actually related to the target language feature.

The think-aloud protocol facilitated gathering a concurrent verbal report, and 
allowed the researcher to understand the internal processing that the language learners used to make specific judgments. The subjects were asked to think out loud into the voice recorder all the thoughts that went through their mind whilst making a judgment on each sentence. In addition, they were told to respond in their native language (English), as it was easier to convey their ideas and could reduce problems in speaking or writing in Thai.

Before the experiment began, a warm-up task was used to familiarize the participants with verbalizing their thoughts. The warmup activity must not be too complicated, such as a problem-solving task, so a fairly simple maze ${ }^{6}$ was selected. To keep the participants concentrating on the stimuli, rather than interacting with the researcher, the researcher sat behind them and audiorecorded their response on MP3. The only prompt phrases used throughout the experiment were Please keep speaking or What do you think about the sentence? This is to avoid the possibility of adding external ideas that may cause the data to be biased. While performing the task, the participants were asked to read the list of 30 test sentences one after another on 30 PowerPoint presentation slides. They were allowed to view the next slides individually after they had finished the current one. Each of the sentences was presented with its phonetic transcription, word-by-word gloss and an English translation, as shown below.

\footnotetext{
${ }^{6}$ see Appendix C
}

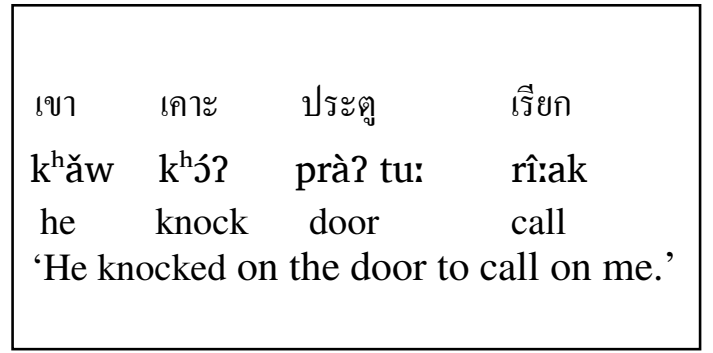

Figure 1 The presentation of an individual sentence on a laptop screen using PowerPoint.

The experiment was conducted with one subject at a time in a private self-study room in the University of Leeds's main library. The entire procedure (from doing the warmup activity to the actual task) lasted between 45-60 minutes, but on average the experiment alone took approximately 30 minutes. None of the participants showed signs of fatigue during or after the test.

\section{Coding and scoring}

Only the 24 sentences containing SVCs were analyzed. The researcher excluded all responses from the six distracters. The patterns of response in this study that were coded as acceptable included "okay", "correct", "right", "fine", "grammatical", "possible", "acceptable" or "I like it.", whereas the response of "not okay", "incorrect", "wrong", "odd", "weird", "unnatural", "ungrammatical", "impossible", "unacceptable", "I don't like it," or "I would not say this," were coded as unacceptable. The calculation of scores was based on the comparison of the participants' judgment and the acceptability status of each sentence as follows.

The judgment would be interpreted as $(+1)$ for each of the sentences of which they 
precisely identified the accuracy status, i.e. when they judged any correct sentence as acceptable and when they considered any incorrect sentence as unacceptable. Conversely, their answer would be interpreted as (-1), if they made an erroneous judgment, i.e. when they considered any correct sentence as unacceptable and judged any incorrect sentence as acceptable. As for "pass", "I don't know.", "I'm not sure.", "I have no idea." or any other phrases that showed uncertainty to discriminate acceptable from unacceptable item, (0) would be applied.

\section{Findings}

The main issue under investigation in this section was whether and to what extent L1 English - L2 Thai learners are sensitive to schematically and pragmatically unacceptable basic Thai SVCs. The data collected were quantitatively analyzed and used to make inferences about their command of the language. If the statistics suggested low $(+1)$ and high (-1), the researcher could utilize the findings to address more exactly which of the erroneous characteristics tend to be problematic for the subjects. The following table sums up the total responses $(n=240)$ from the 10 participants judging 24 target sentences embedded with basic Thai SVCs. All verbal reports were coded and grouped by $(+1),(-1)$ and $(0)$.

The data suggested that, by and large, the ability to discriminate between acceptable and unacceptable items was moderate $(64.17 \%$ or 154 out of the total 240 responses). However, roughly one fifth of all responses $(20.83 \%)$ showed confusion on the SVCs' acceptability status by misjudging correct ones as incorrect, and vice versa. It could be argued that their sensitivity to errors was relatively low as shown by three pieces of supporting evidence. One, the subjects became less likely to identify the acceptability status of incorrect items $(65 / 120)$ compared to the status of correct items (89/120). Two, the number of incorrect sentences being misjudged $(34 / 120)$ was twice as high as their counterpart (16/120). Three, the subjects were more likely to provide an 'undecided' judgment on incorrect items (21/120) than correct ones $(15 / 120)$. To conclude, the participants performed worse when confronting inaccurate items, i.e. they are less sensitive to errors.

Next, the researcher focused only on the unacceptable sentences to examine which of the anomalous characteristics seems to be difficult to recognize. The elicited data were then analyzed according to the 4 characteristics of errors, namely verb alternation, verb choice, redundancy and temporal gap. 
Table 2 The summary of the participants' responses.

\begin{tabular}{|c|c|c|c|c|}
\hline \multirow{2}{*}{\multicolumn{2}{|c|}{ Types of responses }} & \multirow[b]{2}{*}{ Tally } & \multicolumn{2}{|c|}{ Total responses } \\
\hline & & & Number & Percentage \\
\hline \multirow[t]{2}{*}{$(+1)$} & correct items judged as acceptable & $89 / 120$ & \multirow[t]{2}{*}{$154 / 240$} & \multirow[t]{2}{*}{64.17} \\
\hline & incorrect items judged as unacceptable & $65 / 120$ & & \\
\hline \multirow[t]{2}{*}{$(-1)$} & correct items misjudged as unacceptable & $16 / 120$ & \multirow[t]{2}{*}{$50 / 240$} & \multirow[t]{2}{*}{20.83} \\
\hline & incorrect items misjudged as acceptable & $34 / 120$ & & \\
\hline \multirow[t]{2}{*}{ (0) } & correct items left undecided & $15 / 120$ & \multirow[t]{2}{*}{$36 / 240$} & \multirow[t]{2}{*}{15.00} \\
\hline & incorrect items left undecided & $21 / 120$ & & \\
\hline
\end{tabular}

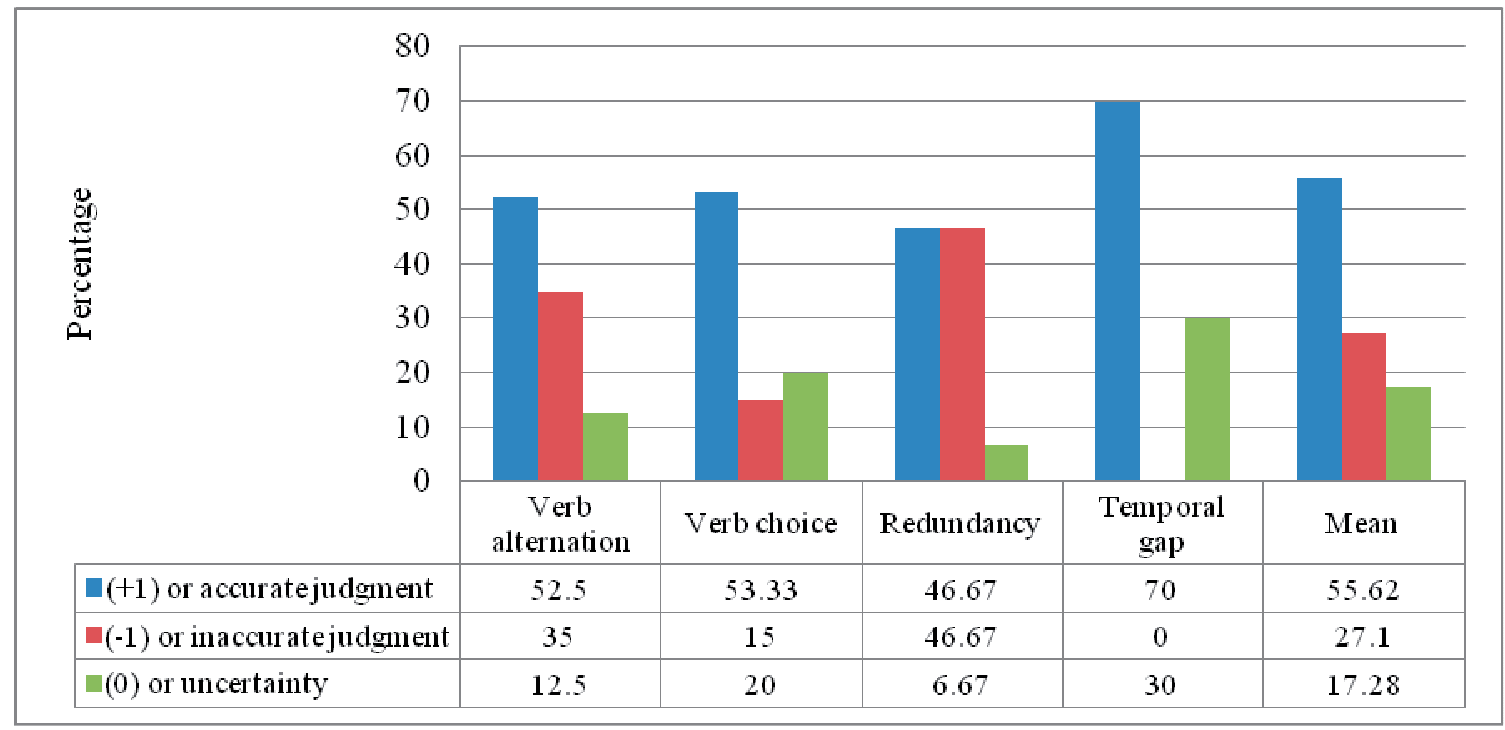

Figure 1 The results of the participants' judgment classified by the characteristics of errors.

Statistically, it is clear that the majority of the participants $(70 \%)$ could successfully detect the anomalies concerning the temporal gap because none of them considered those sentences acceptable. The possible reason why the other $30 \%$ gave the response of uncertainty might be because they could sense the noticeable time span between the two events. However, in the meantime they might have seen some sort of association between those two events, and they were thus unsure whether to supply a conjunction to the sentences.

The average $(+1)$ of $55.62 \%$ showed that in general the ability to detect unacceptable sentences is considered marginally higher than half. There are 2 characteristics that 
appear to be problematic for foreign learners. One concerns redundancy, in which the degree of $(+1)$ and $(-1)$ was of exactly the same rate $(46.67 \%)$. The other erroneous characteristic concerns verb alternation. The responses which were coded as $(-1)$ was as much as one third (35\%), while the responses which were coded as $(+1)$ was only just a little above the half $(52.50 \%)$. In brief, redundancy and verb alternation are the top 2 characteristics of errors that the participants were unable to recognize, whereas temporal gap and verb choice were the kinds of errors that were less likely to be problematic.

\section{Discussion}

\section{Discussion of findings in relation to research questions}

\section{Research question 1}

The question To what extent can English learners distinguish between acceptable and unacceptable Thai basic SVCs? concerned the sensitivity of the subjects when they were presented with the set of Thai sentences embedded with basic SVCs. Half of them were acceptable, whereas the other half were deliberately flawed in a particular way. The results revealed that, on average, only a little more than half of all sentences were correctly identified $(64.17 \%$, or approximately 15 out of 24 sentences). The percentage of ability to detect incorrect sentences as unacceptable ones was even lower $(54.17 \%$ or 6.5 out of 12 incorrect sentences). These statistics obviously reflected the researcher's prior concern about their insensitivity to errors.
In this instance, a few more factors should be taken into consideration. First of all, since all participants knew that their competence was going to be measured and had unlimited time to ponder each of the items, the researcher assumed they performed their best to supply the answers. Second, despite a regular urge to keep them speaking their thoughts out loud, most participants did not show instant interaction with the sentences. The recorded sound clips revealed a short period of silence or muttering to themselves. The researcher could not certify whether this was due to the uncertainty when confronting the SVCs. Third, when the moderately high degree of misjudgment or (-1) was taken into account, it was clear that they had some confusion about the acceptability status of each sentence.

Accordingly, to answer the first research question from the interpretation of data and supporting arguments, it can be postulated that even under certain conditions and only to some extent are L1 English learners relatively insensitive to the anomalies concerning basic Thai SVCs.

\section{Research question 2}

Which of the erroneous characteristics in Thai SVCs tend to be problematic for English learners?' was the other research question to be discussed. The results showed that less than half $(46.67 \%)$ of the items containing malformed SVCs relating to redundancy were identifiable. In addition, the degree of $(+1)$ and (-1) was exactly the same. This indicated that learners' sensitivity to the unnecessary occurrence of the argument is low. As for the errors concerning verb choice and verb alternation, 
the data showed that the subjects also had a moderate sensitivity $(53.33 \%$ and $52.5 \%$ respectively) in distinguishing the acceptable from the unacceptable items. On the other hand, the participants were able to make a correct judgment $70 \%$ of the time with regard to temporal gap errors where the verbs expressed two events with a noticeable time span, rather than one complex episodic event.

In this light, the second research question became answerable. Arranged in respective order, the most to the least problematic characteristic of errors for L1 English learners are redundancy, verb alternation, verb choice, and temporal gap.

\section{Discussion of qualitative data}

The data elicitation method of think-aloud facilitated access to their genuine ability of sentence processing. With this extra piece of information, the section provides further explanation and discussion.

\section{Discussion of their sensitivity to errors}

This section deals with the incorrect items in which the subjects could sense anomalies and rectify them. They were erroneous SVCs regarding temporal gap and verb choice.

The statistics showed that the temporal gap was the most recognizable erroneous characteristic by the participants, with the highest percentage of $(+1)$ at $70 \%$ and without any $(-1)$. The followings are some target sentences from the experiment.

$$
\begin{aligned}
& \text { (12) * Pa:ri: } \quad \underline{6}^{\mathrm{h}} \text { û:a } \\
& \text { Aari (proper name) believe } \\
& \text { rû:an p } \mathrm{p}^{\text {ȟ̃: }} \quad \text { bò:k } \quad \text { nó:n sǎ:w } \\
& \text { ghost stories tell younger sister } \\
& \text { * 'Aari believed in ghost stories. ( ) } \\
& \text { told her sister.' } \\
& \text { (13) * 2̧̂:m } \\
& \oint^{\mathrm{h}} \text { á ná? } \\
& \text { Oom (proper name) win } \\
& \text { ka:n prà? kù:at di: tçaj } \\
& \text { competition happy } \\
& \text { *'Oom won a competition. ( ) was } \\
& \text { happy.' }
\end{aligned}
$$

The participants were able to perceive the association between the actions (or the states) denoted by both pairs of underlined verbs in each sentence, but yet again there were noticeable delays. In correcting these sentences, the majority of participants supplied a conjunction as in (14), a coordinator as in (15) or a complementizer as in (16) as appropriate to fix the error sentences. For instance,

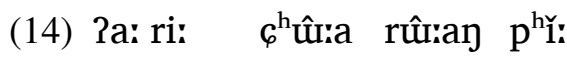
Aari believe story ghost cuun bò:k nó:y să:w so tell younger sister 'Aari believed in ghost stories, so she told her younger sister.'

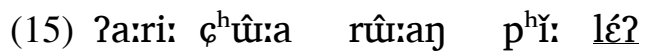
Aari believe story ghost and bò:k rû:ạ ní: kè: nó:̣ să:w tell story this to younger sister 'Aari believed in ghost stories and told this to her younger sister.' 
(16) Pa:ri: bj̀:k nó:y sǎ:w wâ:

Aari tell younger sister (comp)

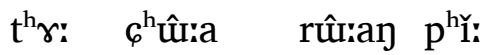

she believe story ghost

'Aari told her younger sister that she believed in ghost stories.'

Here are some illustrations of how the participants rewrote sentence (13) properly.

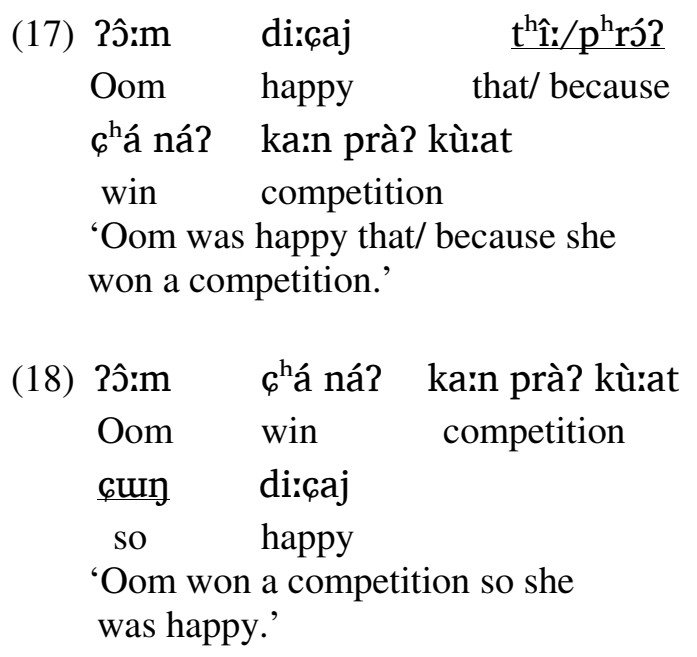

Next, the sentence below is one of the unacceptable sentences containing the wrong verb choice.

\section{(19) * tam rù:at $\mathrm{k}^{\mathrm{h}} \mathrm{a}: \mathrm{p}$ hâ: rá:j Gèp Police kill criminal hurt * 'A policeman killed a criminal. The criminal was hurt.'}

Using an inappropriate choice of verb in (19) resulted in an incomprehensible meaning in both languages because it violated the aforementioned pragmatic constraint. To recapitulate, pattern 4 allows a primary action verb to co-occur with a physical process. Although the verbs $k^{h} \hat{a}^{\text {r }}$ ('kill') and cèp ('hurt') respectively belonged to those verb classes, the event expressed by the two verbs in the construction is inconceivable based on realworld knowledge. The reason is that death is the one and only sensible consequence from being killed. When encountering this item, most of the participants felt uncertain and judged it unacceptable. On the other hand, some tried to interpret the sentence to the most comprehensible way by employing the relative clause construction.
(20) tam rùrat $\quad \mathrm{k}^{\mathrm{h}} \mathrm{a}: \quad \mathrm{p}^{\mathrm{h}} \mathrm{u}:$ rá:j policeman kill criminal $\mathrm{k}^{\mathrm{h}}$ on $\quad \mathrm{t}^{\mathrm{h}} \mathrm{i}$ : $\quad$ è̀ classifier relativizer hurt 'A policeman killed the criminal who was hurt.'

\section{Discussion of their insensitivity to errors}

This section is devoted to discussing the characteristic of errors that the participants were unaware of. First of all, redundancy seems to be the most problematic characteristic to L1 English - L2 Thai learners in this study. The findings showed the majority of them were unable to recognize an unnecessary argument in the SVCs, so they judged those unacceptable sentences as acceptable ones.

It is worth pointing out that the participants were more sensitive to (11) where there was a repetition of the noun sû:a 'shirt'. On the other hand, when the excessive unit added to 
the sentence was a pronoun, the participants became less likely to give a precise judgment. The following examples contain the pronoun man 'it' referring to pla: ('fish') and ce:kan ('vase') which are the objects of the initial verbs $t^{h} \hat{\text { s̀t }}$ ('fry') and pàt ('push') respectively. However, the relationship between pronoun man and the second verb is different. That is, man in (21) functions as the direct object or patient of the transitive verb kin ('eat'), whereas man in (22) is the subject or agent of the intransitive verb tغ̀:k ('break').

$$
\begin{aligned}
& \text { (21) * mê: } \quad \mathrm{t}^{\mathrm{h}} \hat{\mathrm{j}}: \mathrm{t} \text { pla: kin man } \\
& \text { mom fry fish eat it } \\
& \text { * 'Mom fried a fish to eat. } \\
& \text { (22) * pâ: pàt } 6 \varepsilon \text { : kan man tè:k }
\end{aligned}
$$

Secondly, the audio clips revealed that although various correct sentences were judged acceptable, some of the participants showed their instant dislike of such acceptable SVCs and tended to find an alternative ways to formulate them. Some reactions consisted of, for example, "It looks fine, but I do not like this sentence.", "Maybe it is ok for colloquial Thai. I find people tend to shorten everything." or I don't think I'm going to use this sentence. I would probably say..." [sic]

When analyzing the corrections or alternative sentences given by participants, the researcher found one thing in common.
The subjects were likely to add an overt conjunction between the two concatenating verbs, believing that the meaning of the sentences would remain the same despite a different syntactic structure. The most frequently used conjunctions comprise subordinators, e.g. con or con krà? $t^{h} a ̂ \eta$ ('until') and $p^{h} \hat{u ̂}: a$ ('in order to'); a coordinator lદ́? 'and', as well as, a discourse marker léw kô: ('and then') (Prasithrathsint 2010). As for the reasons why some of the subjects behaved in this fashion, it is probable that they thought that the subordinate or coordinate constructions convey similar meaning like the SVCs do, but to them the SVCs sounded more colloquial. In sentence (23) to (27), the underlined parts presented the corrections made by the participants. Even though the intervention does not result in unacceptable sentences, the newly reconstructed sentences can convey different readings or sound awkward.

(23) nák fút bo:n lóm $\quad$ con football player trip over until khă: $\mathrm{p}^{\mathrm{h}} \mathrm{l}: \mathrm{n}$ leg strain 'The football player tripped over and over again until he strained his leg.'

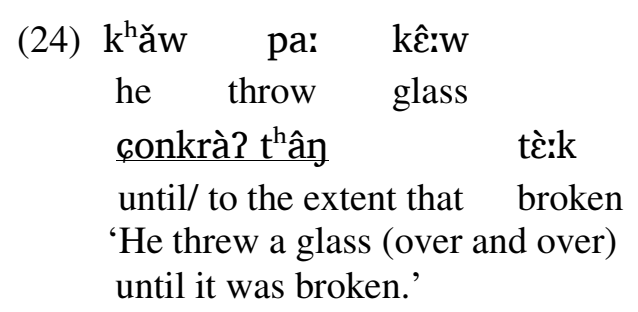


MANUSYA: Journal of Humanities, Special Issue No 20, 2014

(25) $k^{\text {hăw }} k^{\text {h }}$ ? prà?tu: p $^{\text {h }}$ û:a rî:ak he knock door in order to call 'He knocked on the door in order to call on (someone).'

(26) fâ:j Fai (proper name) walk and talk $\mathrm{t}^{\mathrm{h}} \mathrm{O}$ : rá sàp phone 'Fai walked and talked on the phone' (without a simultaneous reading).

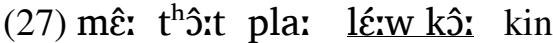
mom fry fish and then eat 'Mom fried the fish, then ate it (later).'

To differentiate the SVCs from other semantically similar constructions, the researcher would like to reiterate a general feature of the SVCs that together all verbs in the string function like a single predicate and denote one complex event. The intervention of $60 n$ or $60 n k r a ̀ ? t^{h} a \hat{\eta}$ ('until') in (23) and (24) reconstructed the sentences with subordinate construction to denote a different conceptualization, i.e. the events became independent from each other. In this case, the subordinator conveyed the durative and attempt-making interpretation. It implied that the agent carried out a particular action repeatedly for a certain period of time until another event took place. Supposing that the football player keeps tripping over and over, the interpretation would sound very odd. Rather, the resulting event should be perceived as an expected outcome occurring immediately after the causing event, i.e. once one throws a glass, it is definitely broken.
As for (25), the action of $k^{h}$ '́? ('knock') was considered a conventional means to rî́ak ('call on [someone]'). Moreover, in reality both actions overlap and cannot be separated from each other. The insertion of the subordinator $p^{h}$ û:a ('in order to') not only splits these connecting events, but may also hint an unusual purpose of performing the initial verb.

In (26), the two verbs strung together as an SVC show that the agent is performing an action of $k^{h} u j$ ('talk') and $d r: n$ ('walk') at the same time. However, the coordinator lḱ? ('and') attenuated the simultaneity of the events, and suggests that both actions might not occur at the same place and time.

As for (27), the discourse marker lé:w kô: ('and then') made both actions become independent from each other because there is a noticeable time span between them. Moreover, the interpretation that the second verb is the purpose of performing the initial verb is lost. In this case, kin ('eat') does not necessarily happen right after $t^{h} \hat{\text { ôt }}$ ('fry'), i.e. the two actions may occur at different times and places.

"The perception of events expressed by serial verbs as a single event is repeatedly reported to be clear intuition of native speakers" (Duries 1997: 291). This intuition might not exist in the mind of the learners of Thai as a second language whose native languages are non-serializing. It is possible that speakers of a non-serializing language might conceptualize the events in a different way and this consequently reflects on how 
they perceive basic Thai SVCs. Using reasons, rather than intuition, three of the participants rationalized their dislikes of well-formed basic SVCs by mentioning the formal instruction. One participant stated, "we have been taught to make a complete sentence, but when I was in Thailand, I noticed how people speak differently from what we learn in class" [sic]. Although the researcher was unable to offer arguments either for or against this claim, having neither learning materials nor evidence from classroom observation at hand, it is crucial to bring this point up for further investigation.

Thirdly, apart from the topics discussed above, one interesting phenomenon found whilst collecting the data was also the alternations between the verbs in SVCs, and consequently changing correct sentences to incorrect ones (and vice versa). The point the researcher would like to raise here is that this was not a random mistake but rather was made consistently by the same participant. For example,

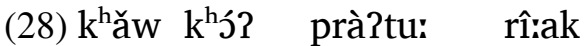 he knock door call 'He knocked on the door to call on (someone).'}

When sentence (28), which is acceptable, was presented to that participant, he then considered it incorrect and reconstructed the sentence by switching the order of the two verbs in the SVCs. Thus, his correction resulted in an unacceptable sentence, like

$\begin{array}{cccl}\text { *kâw } & \text { rî:ak } & \mathrm{k}^{\mathrm{h}} \text { ว́? } & \text { prà?tu: } \\ \text { he } & \text { call } & \text { knock } & \text { door }\end{array}$

(impossible to translate)
In addition, the same participant confidently judged the following sentence, which is incorrect, as an acceptable sentence.

$$
\begin{aligned}
& \text { (29) *ka:n da: } \quad \text { ró:n p p le:n } \\
& \text { Kanda(proper name) } \\
& \text { dr:n } \\
& \text { walk a song } \\
& \text { (impossible to translate) }
\end{aligned}
$$

As for this case, the participant supported his decision by saying "Normally, in Thai, the more prominent part should come first". He took for granted that the canonical Thai syntactic construction head-initial, as shown in (30) and (31), can be applied to the order of verbs in Thai basic SVCs.

$$
\begin{aligned}
& \text { (30) bâ:n máj } \\
& \text { house } \quad \begin{array}{l}
\text { wood } \\
\text { 'A wooden house' }
\end{array} \\
& \begin{array}{c}
\text { (31) phê:t jà:y sù? phâ:p } \\
\text { speak politely } \\
\text { 'Speak politely' }
\end{array}
\end{aligned}
$$

Accordingly, he placed the verb expressing the action that he perceived as more prominent in the initial position; whereas the other verb denoting the action that he found less prominent in the second position. From the example in sentence (28) and (29), he considered rîak ('call') and róry phle:y ('sing') more obvious than $k^{h}$ 's 'knock' and dr:n ('walk'). However, the proper way to form SVCs in Thai, as the paper argued earlier is that the serializability is governed by the verb classes, the semantic properties 
of each verb itself and the possibility in the real-world.

\section{Conclusion}

It is obvious that English verb conjugation and SVCs are totally different. Thai verbs have neither inflectional change in tense, aspect or mood (TAM), nor distinction between finite and non-finite verb forms. Therefore, when they juxtapose together in a long series of verbs, the construction looks even more complicated for speakers of a non-serializing language.

The current study concerned Thai as an L2 language, specifically when native English speakers had to deal with SVCs which do not exist in their mother tongue. The scope was narrowed down to basic Thai SVCs, which comprise a pair of nongrammaticalized and non-complement taking verbs. The experiment was conducted to test L1 English - L2 Thai learners on distinguishing between acceptable and unacceptable SVCs, and to specify the characteristics of errors that tend to be problematic to them. An AJT and thinkaloud protocol were used to collect the data.

The results revealed that L2 Thai learners can only to some extent distinguish between acceptable and unacceptable sentences embedded with basic SVCs, as well as detect the anomalies. Statistically, malformed basic SVCs containing redundancy are the most error-prone characteristic. The qualitative data revealed that the nature of common mistakes is related to attempts to insert linkers between the verbs in the series. It might be inferred that this originates from the learners' misunderstanding when hearing Thais using SVCs in their everyday conversation, and assuming that their function was to sound colloquial. In fact, the use of SVCs reflects the elaboration of a multi-faceted event which is conceptualized or perceived by native Thais as one single complex unit.

Although it may not be possible to generalize the findings to the majority of L1 English learners of Thai, this study provides some initial support to the claim that SVCs are difficult to deal with. Ultimately, it is hoped that the current research would contribute to pedagogical linguistics and benefit scholars working on Thai, Thai language teachers as well as learners.

\section{References}

Aikhenvald, Alexandra Y. 2006. Serial verb constructions in typological perspective. In Serial verb constructions: A cross linguistic typology, edited by Alexandra Y. Aikhenvald and R. M. W. Dixon, pp. 1-68. New York: Oxford University Press.

Duries, Mark. 1997. Grammatical Structures in verb serialization. In Complex Predicates, edited by Alex Alsina, Joan Bresnan and Peter Sells, pp. 289-354. Stanford: CSLI publications.

Prasithrathsint, Amara. 2010. Complex sentence and discourse: The problems with overlapping and the solutions to distinguish them (ประโยคซับซ้อนและสัมพันธสาร: ปัญหาความซ้อนเหลื่อมและวิธีแยกให้ ต่างกัน). Paper presented at National 
academic conference on a new dimension in Thai grammatical analysis, 12 - 13

July, 2010, Bangkok.

Thepkanjana, Kingkarn. 2006. Properties of events expressed by serial verb constructions in Thai.Paper presented at the Eleventh Biennial Symposium:

Intertheoretical approaches to complex verb constructions, 16-18 March, 2006,Texas.

Thepkanjana, Kingkarn. 2008. Verb serialization as a means of expressing complex events in Thai. In Asymmetric events, edited by Barbara Lewandowska Tomaszczyk, pp. 103-120.Amsterdam: John Benjamins. 


\section{Appendix A The entire set of the target items included in the study}

NB. The order of the 24 test sentences has been rearranged as follows:

- 1 to 12 are acceptable.

- 13 to 15 are unacceptable because of the erroneous characteristic known as verb alternation.

- $\quad 16$ to 18 are unacceptable because of the erroneous characteristic known as verb choice.

- 19 to 21 are unacceptable because of the erroneous characteristic known as temporal gap.

- 22 to 24 are unacceptable because of the erroneous characteristic known as redundancy.

1. เขา เคาะ ประตู เรียก

k hăw $k^{\text {hó? }}$ prà? tu: rî̀ak

he knock door call

'He knocked on the door to call on (someone).'

2. เขา ส่ายหน้า ปฏิเสธ

khăw sà:j nâ: $\quad p$ tì? sè:t

he shake one's head refuse

'He shook his head to refuse.'

3. พล

วิ่ง ออกกำลังกาย ทุก เย็น

$\mathrm{p}^{\mathrm{h}}$ on

wîn 2j̀:k kam lạ ka:j

$\mathrm{t}^{\mathrm{h}}$ úk jen

Phon(proper name)

run work out

every evening

'Phon works out by running every evening.'

4. พ่อครัว ใช้ มีด หั่น ไก่

$\mathrm{p}^{\mathrm{h}} \hat{\text { sk }}$ ru:a $\varphi^{\mathrm{h} a ́ j}$ mîtt hàn kàj

chef use knife slice chicken

'A chef used a knife to slice chicken.'

5. มล

ปอก ส้ม กิน

mon

pj̀:k sôm kin

Mon(proper name) peel orange eat 
'Mon peeled an orange to eat.'

6. พ่อ เปิด ทีวี ดู

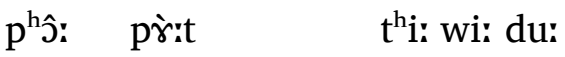

dad turned on TV watch

'Dad turned on the TV to watch.'

7. น้องชาย ของฉัน ทาน ข้าว หมด

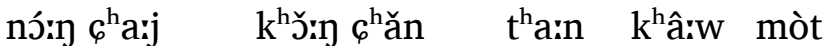

brother my eat rice nothing left

'My brother finished all the rice.'

8. จันทร์ อ่าน หนังสือ จบ แล้ว

çan Tà:n năy sǔ: Gòp lé:w

Chan (proper name) read book finish already

'Chan has already read the whole book.'

9. นักฟุตบอล ล้ม ขา แพลง

nák fút bə:n lóm $\quad \mathrm{k}^{\mathrm{h}}$ ă: $\quad \mathrm{p}^{\mathrm{h}} \mathrm{l}$ :’

football player trip over leg strain

'A football player tripped over and strained his leg.'

10. ฝ้าย เดิน คุย โทรศัพท์

fâ:j $\quad \mathrm{d}$ r:n $\quad \mathrm{k}^{\mathrm{h}} \mathrm{uj} \quad \mathrm{t}^{\mathrm{h}} \mathrm{O}$ : ra sàp

Fai walk talk phone

Fai was on the phone whilst walking.

\begin{tabular}{clll}
\hline 11. แม่ & ยืน & รดน้ำ & ต้นไม้ \\
mê: & jui:n & rót ná:m & tôn máj \\
mom & stand & water & plants
\end{tabular}

Mom was standing whilst watering the plants. 
12. กิ๊ก

$\begin{array}{ll}\text { เดิน } & \text { ชม } \\ \text { dr:n } & \text { t } \text { h }^{\mathrm{h}} \text { om } \\ \text { walk } & \text { admire }\end{array}$

ดอกไม้

ใน สวน

kík

walk admire

dj̀:k máj

naj sǔian

Kik

flower

in garden

Kik was walking and admiring the flowers in the garden.

13. เขา จุด สูบ บุหรี่

kăw cùt sù:p bù? rì:

He lit smoke a cigarette

'He lit a cigarette to smoke.'

14. กานดา

ร้องเพลง เดิน

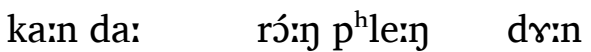

Kanda sing walk

Kanda was singing whilst walking.

15. คุณครู กอด อก ยืน

$\mathrm{k}^{\mathrm{h}}$ un $\mathrm{k}^{\mathrm{h}} \mathrm{ru:} \quad$ kə:d $\quad \grave{s} \mathrm{k} \quad$ ju:n

teacher hug chest stand

A teacher stood with arms crossed.

16. เขา ย่าง ปลา กลืน

kñw jâ:y plà: k lư:n

he grill fish swallow

'He grilled a fish and swallowed it.'

17. ตำรวจ ฆ่า ผู้ร้าย เจ็บ

tam rù:at $\quad \mathrm{k}^{\mathrm{h}} \hat{\mathrm{a}} \mathrm{i} \quad \mathrm{p}^{\mathrm{h}} \hat{\mathrm{u}}$ rá:j $\quad$ cèp

Police kill criminal hurt

'A policeman killed a criminal. The criminal was hurt.' 
18. ปิติ

pì?tì?

Piti (proper name)
นอน

nว:n

recline
ทำอาหาร

$\mathrm{t}^{\mathrm{h}} \mathrm{am}$ Pa: hă:n

cook

Piti cook in his reclining posture.

19. เขา ปิด ไฟ ออก จาก ห้อง

k ăw pìt faj lò:k cà:k hô:y

he turn off light leave from room

'He turned the light off. He left the room.'

20. อารี

เชื่อ เรื่องผี บอก น้องสาว

Pa: ri:

$$
\zeta^{\mathrm{h}} \text { û:a }
$$

rû:ał phř: $\quad$ bj̀:k nó:y să:w

Aari(proper name)

believe

ghost stories tell sister

'Aari believed in ghost stories and told these to her sister.'

21. อ้อม

ชนะ

การประกวด

ดีใจ

ใวิ:m

$\zeta^{\text {há ná? }}$

ka:n prà? kùrat

di: 6 aj

Oom (proper name)

win

competition

happy

'Oom won a competition and was happy.'

22. ฉัน ซัก เสื้อ รีด เสื้อ

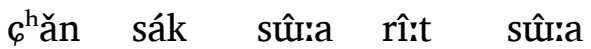

I wash shirt iron shirt

'I washed a shirt and ironed that shirt.'

23. แม่ ทอด ปลา กิน มัน

mê: $\mathrm{t}^{\mathrm{h}} \hat{\mathrm{s}}: \mathrm{t}$ pla: kin man

mom fry fish eat it

'Mom fried a fish to eat.' 
MANUSYA: Journal of Humanities, Special Issue No 20, 2014

24. ป้า

$$
\text { ปัด แจกัน }
$$

มัน แตก

pâ:

pàt $\quad 6 \varepsilon$ : kan

man tè:k

Auntie

push vase

it break

'Auntie (accidentally) pushed a vase and it broke into pieces.'

\section{Appendix B The distracters (6 sentences)}

25. ธงชาติ

ไทย มี สาม สี

$\mathrm{t}^{\mathrm{h}}$ on $6^{\mathrm{h}}$ a:t $\quad \mathrm{t}^{\mathrm{h}} \mathrm{aj} \quad \mathrm{mi}: \quad$ sǎ:m sǐ:

flag Thai has three colour

'Thai flag consists of three colours.'

26. เดือนมกราคม

มา ก่อน เดือนกุมภาพันธ์

duran mak ka ra: $\mathrm{k}^{\mathrm{h}}$ om

ma: kə̀:n duran kum $\mathrm{p}^{\mathrm{h}} \mathrm{a}$ : $\mathrm{p}^{\mathrm{h}} \mathrm{an}$

January

come before February

'January comes before February.'

\begin{tabular}{llllll}
\hline 27. ก๋วยเตี๋ยว & ชาม & นี้ & ราคา & สามสิบห้า & บาท \\
kǔaj tǐ:aw & c $^{\mathrm{h}} \mathrm{a}: \mathrm{n}$ & ní: & ra: $\mathrm{k}^{\mathrm{h}} \mathrm{a}:$ & să:m sìp hâ: & bà:t \\
noodles & bowl & this & cost & thirty five & baht
\end{tabular}

'This bowl of noodles costs me thirty five baht.'

28. แนน

ให้ ขนม เมย์

ne:n

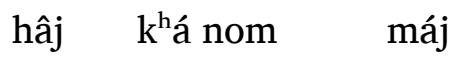

Nan (proper name) give sweet/snack May (proper name)

'Nan gave May sweet/ snack.'

29. นักเรียน ต้อง ทำ การบ้าน

nák ri:an tô:n $\quad \mathrm{t}^{\mathrm{h}} \mathrm{am}$ ka:n bâ:n

student must do homework

'Students must do their homework.' 
30. ถนน

$\mathrm{t}^{\text {hà nǒn }}$

road
ขรุขระ

krú krá?

rough

'The road is rough.'

\section{$\underline{\text { Appendix C The warm-up task (the maze) }}$}

The task here is to help you familiarize yourself with verbalizing your thoughts and to ensure that you understand the instructions.

Direction you need to find your way from the position A through the maze presented below to the position B. As you work your way in the maze, try to speak your thought out loud into the voice recorder while you perform the task, not after. Please try to speak in a clear voice.

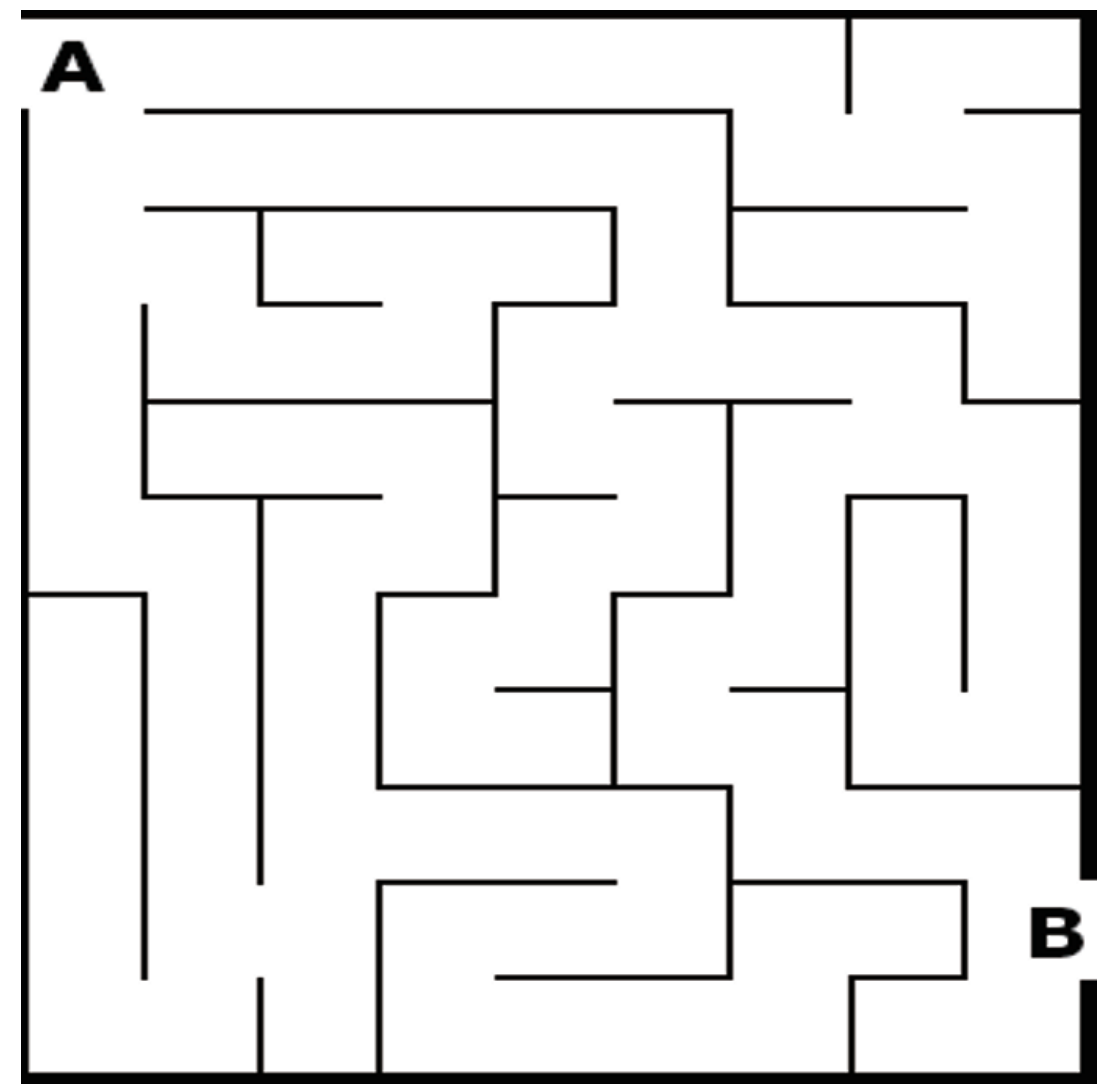

